\title{
A BIOPOLÍTICA EM MICHEL FOUCAULT E GIORGIO AGAMBEN: MODERNIDADE, SOBERANIA E EXCLUSÃO
}

\author{
BIOPOLITICS IN MICHEL FOUCAULT AND GIORGIO AGAMBEN: MODERNITY, SOVEREIGNTY
}

AND EXCLUSION

André Simões Chacon Bruno*

\begin{abstract}
Resumo:
Esta pesquisa tem como principal escopo promover uma explanação sobre o conceito de biopolítica, termo este que, após ter passado por uma profunda ressignificação com os trabalhos de Michel Foucault, veio a se instalar no centro dos debates contemporâneos. Desta forma, o trabalho promove em um primeiro momento uma reconstrução teórica sobre como o termo foi tratado por Foucault em diversas fases de sua obra. Após esta etapa, o trabalho torna sua atenção aos escritos de Giorgio Agamben, o qual toma Foucault como ponto de partida, mas que possui, no entanto, uma acepção própria, diversa da de Foucault, sobre o conceito de biopolítica. Desta forma, passa-se então a caracterizar o significado da biopolítica em Agamben, delimitando seu alcance, suas diferenças em relação a Foucault, bem como também as consequências advindas desta caracterização.
\end{abstract}

Palavras-chave: Biopolítica. Michel Foucault. Giorgio Agamben.

\begin{abstract}
:
This essay has as its main purpose to promote an explanation of the concept of biopolitics, a term that came to take a center stage in contemporary debates, after having gone through a deep resignification with the works of Michel Foucault. In this way, the first part of this essay is a theoretical reconstruction on how the term was treated by Foucault in several phases of his work. After that, the essay turn its attention to the writings of Giorgio Agamben, which takes Foucault as a point of departure, but which has, nevertheless, a proper conception, different from Foucault's, on the concept of biopolitics. In this way, it goes on to characterize the meaning of biopolitics in Agamben, delimiting its scope, its main differences in relation to Foucault, as well as the consequences that comes from this characterization.
\end{abstract}

Keywords: Biopolitics. Michel Foucault. Giorgio Agamben.

\section{Introdução}

O presente trabalho tem como principal escopo promover uma explanação sobre o conceito de biopolítica, termo apresentado por Michel Foucault para o grande público em 1976, no último capítulo de História da Sexualidade I, A vontade de saber,

\footnotetext{
* Mestre e Doutorando em Filosofia e Teoria Geral do Direito pela Faculdade de Direito da USP. 
desenvolvido também no mesmo ano no curso proferido no Collège de France, publicado posteriormente sob o título Em defesa da sociedade (DUARTE, 2008, p. 1), e que desde então passou a ser objeto de pesquisa e discussão por diversos autores, dentre eles o teórico italiano Giorgio Agamben. ${ }^{1}$

Nesse sentido, o artigo busca fazer em um primeiro momento uma reconstrução teórica sobre como o termo foi tratado por Foucault, partindo da sua ideia da superposição de diversas técnicas de poder: começando pelo sistema jurídico da soberania, para entrar em um segundo momento no mecanismo disciplinar, para chegar, por fim, ao que Foucault começa chamando de dispositivos de segurança e que posteriormente passa a denominar de mecanismos (ou controles) reguladores, os quais se dão não mais somente no âmbito das técnicas individualizantes do poder disciplinar, mas principalmente no contexto da emergência do fenômeno da população, isto é, a biopolítica.

Uma vez concluído este percurso o trabalho torna sua atenção aos escritos de Giorgio Agamben, no desiderato de identificar e explicitar qual é o significado da biopolítica em sua perspectiva, de que maneira ela se diferencia da forma como Foucault a entendia e quais as principais consequências daí decorrentes. Quanto a isto, parte-se da premissa que embora Agamben tenha se inspirado para trabalhar na questão da biopolítica em Foucault, devido ao fato de que para Agamben a biopolítica toma na política ocidental uma verdadeira forma ontológica, as perspectivas de ambos os autores possuem uma essencial diferença constitutiva, a qual se pretende aqui esclarecer e detalhar.

Sabe-se que para Agamben o que caracterizaria a política moderna não seria tanto a inclusão da zoé na pólis, nem simplesmente o fato de que a vida como tal venha a ser um objeto eminente dos cálculos e previsões do poder estatal (o advento da biopolítica e dos dispositivos de segurança), mas o fato de que, simultaneamente ao processo que leva a exceção a se tornar em todos os lugares a regra, conforme a intuição benjaminiana na oitava tese sobre o conceito de história, o espaço da vida nua, situado originariamente à margem do ordenamento, vem progressivamente a coincidir com o próprio espaço político, de forma que os limites entre a exclusão e a inclusão, o externo e o interno, a forma de vida politicamente organizada da bíos e a nudez e o abandono da zoé terminam por entrar em uma zona de irredutível indistinção. Assim, em seguida, de forma a caracterizar na integralidade a acepção biopolítica de Giorgio Agamben, é introduzido no debate a figura

\footnotetext{
É necessário observar, no entanto, que Michel Foucault não cunhou o termo biopolítica. Ele repropôs e requalificou o seu conceito, o que veio a acarretar uma profunda modificação em todo o espectro da filosofia política, de modo que a noção de biopolítica, desde então, não apenas se instalou no centro do debate internacional, mas abriu mesmo uma fase inteiramente nova na reflexão contemporânea (ESPOSITO, 2017, p. 19). Para uma referência completa sobre os termos, contextos e sentidos dos primeiros usos do termo, consultar o primeiro capítulo de Bios: biopolítica e filosofia (ESPOSITO, 2017).
} 
do homo sacer, precisamente o habitante desta zona de indiscernibilidade, que serve de paradigma para sua análise da política contemporânea.

De qualquer forma, fala-se aqui de um conceito que habita o campo semântico da modernidade, da soberania e da exclusão, pois, como será visto ao longo deste trabalho, a dimensão que a biopolítica assume no contexto do pensamento dos autores aqui escolhidos implica no radical questionamento das bases mais fundamentais de nossa tradição política. Trata-se, portanto, de um conceito importantíssimo, e que necessita ser compreendido em sua inteireza, pois o que a abordagem biopolítica lega para a nossa política, da maneira como ela se deu, é a interconexão de uma enorme gama de problemas e de negativas consequências, os quais serão em seguida devidamente delimitados e confrontados. Afinal, no contexto da política ocidental, visualizada sob uma perspectiva originariamente biopolítica, de acordo com Giorgio Agamben (2010a, p. 18),

\begin{abstract}
Até que, todavia, uma política integralmente nova-ou seja, não mais fundada na exceptio da vida nua - não se apresente, toda teoria e toda praxe permanecerão aprisionadas em um beco sem saídas, e o "belo dia" da vida só obterá cidadania política através do sangue e da morte ou na perfeita insensatez a que a condena a sociedade do espetáculo.
\end{abstract}

Foucault: soberania, poder disciplinar e biopolítica

O modo como Giorgio Agamben inicia sua obra Homo sacer: o poder soberano e a vida nua I, com a enunciação das duas diferentes formas como os gregos compreendiam e exprimiam o conceito de vida, já foi insistentemente trabalhado e relembrado em diversas ocasiões e por diferentes autores. No entanto, este movimento merece ser aqui mencionado, pois além de ajudar a compreender como o conceito de biopolítica tomará forma em seu pensamento, ele também permite ir já de modo certeiro na decisiva formulação do conceito por Foucault.

De acordo com Agamben (2010a, p. 9), os gregos não possuíam um termo único para exprimir o que queremos dizer com a palavra vida. Deste modo, serviam-se de dois termos semântica e morfologicamente distintos para caracterizá-la: zoé, o qual exprimia o simples viver, comum a todos os seres vivos (a exemplo dos homens, animais e mesmo os deuses), e bios, o qual, por sua vez, indicava uma forma de vida, ou seja, a maneira ou forma de viver própria de um indivíduo ou de um grupo. Essa divisão causava uma cisão: o âmbito da zoé, enquanto simples vida natural, ficava excluída da pólis propriamente dita, restando confinada, como mera vida reprodutiva, na esfera da ôkkos; enquanto a bios, de modo oposto, identificava-se à vida politicamente qualificada, ou seja, à vida do cidadão na pólis. 
Agamben (2010a, p. 10) continua esta linha de pensamento dizendo que é representativo, desta forma, que num trecho que se tornaria canônico para a tradição política ocidental, Aristóteles defina a meta da comunidade perfeita justamente opondo o simples viver (to zên) à vida politicamente qualificada (tò êu zên): "ginoméne mèn oûn tồ zên héneken, ồsa dè tồ ề zên 'nascida em vista do viver, mas existente essencialmente em vista do viver bem"'. Assim, de acordo com Agamben (2010a, p. 1011), é em referência a esta definição que Foucault, ${ }^{2}$ ao final de $A$ Vontade de Saber, vai indicar o processo pelo qual, nos limiares da Idade Moderna, a vida natural começa a ser incluída nos mecanismos e nos cálculos do poder estatal, transformando-se a política em biopolítica, de modo que, de acordo com Foucault (2017, p. 154-155): "O homem, durante milênios, permaneceu o que era para Aristóteles: um animal vivo e, além disso, capaz de existência política; o homem moderno é um animal em cuja política sua vida de ser vivo está em questão". Com efeito, como escreve Foucault (2010, p. 200-201, grifo nosso) em Em defesa da sociedade,

Parece-me que um dos fenômenos fundamentais do século XIX foi, é o que se poderia denominar a assunção da vida pelo poder: se vocês preferirem, uma tomada de poder sobre o homem enquanto ser vivo, uma espécie de estatização do biológico ou, pelo menos, uma certa inclinação que conduz ao que se poderia chamar de estatização do biológico. Creio que, para compreender o que se passou, podemos nos referir ao que era a teoria clássica da soberania que, em última análise, serviu-nos de pano de fundo, de quadro para todas essas análises sobre a guerra, as raças, etc.

Estas questões inevitavelmente fazem referência à problemática do poder. Sabe-se, contudo, quanto a isto, que Foucault se recusou insistentemente em fazer uma teoria unitária do poder. Em verdade, Foucault constantemente apontava para a necessidade de se promover um abandono da abordagem tradicional do problema do poder, ${ }^{3}$ o qual

2 Vale ressaltar, neste momento, a proximidade teórica existente entre os dois autores. Agamben, já na introdução de Homo sacer, deixa bem claro que uma de suas intenções é a de continuar as investigações deixadas inacabadas por Foucault (NASCIMENTO, 2012, p. 108). Nesse sentido, é também esclarecedora a Advertencia dada por Agamben (2010b, p. 9-10) em "Signatura rerum: sobre el método": "Los tres estudios aquí reunidos contienen las reflexiones del autor sobre sendos problemas específicos de método: el concepto de paradigma, la teoría de las signaturas y la relación entre historia y arqueología. Si estas reflexiones se presentan siempre como una indagación sobre el método de un estudioso, Michel Foucault, de quien el autor en los últimos años ha tenido ocasión de aprender mucho, es porque uno de los principios metodológicos no discutidos en el libro - principio que el autor debe a Walter Benjamin - sostiene que la doctrina sólo puede exponerse legítimamente bajo la forma de la interpretación. En los tres estudios, el lector atento sabrá distinguir entre aquello que debe referirse a Foucault, lo que debe atribuirse al autor y lo que vale para ambos".

3 Direcionamento metodológico que Foucault aplicou não somente ao problema do poder, mas também em seus vários outros estudos. Nesse sentido, referindo-se ao eixo dos deslocamentos de pesquisa realizados 
esteve sempre baseado em modelos jurídicos institucionais (a definição da soberania, a teoria do Estado), para então assumir a direção de uma análise dos modos concretos pelos quais o poder penetra o corpo dos sujeitos e em suas formas de vida (AGAMBEN, 2010a, p. 12).

De fato, Foucault (2010, p. 21) realmente não intentava fazer uma teoria sobre o poder, mas sim tentar compreender o "como" do poder. De acordo com Márcio Alves da Fonseca (2012, p. 95), a isto corresponderia o que se pode denominar de uma "analítica do poder", o que é fundamentalmente diferente de se fazer uma "teoria" do poder. Uma teoria tem como pressuposição a identificação de um objeto, e toma, como ponto de partida, a determinação de algo como o "ser" do poder, a partir do qual é possível fazer uma série de descrições sobre sua estrutura, regras de funcionamento e efeitos. Diferentemente, uma analítica do poder não parte da pressuposição de uma essência, não quer definir "o" poder, limitando-se a perceber quais são as diferentes estratégias a que se chama "poder".

Nesse contexto, pode-se dizer que a afirmação foucaultiana assumia a seguinte significação: tentar apreender, por um lado, as regras de direito que formalmente delimitam o poder, e, por outro, a outra extremidade, que seriam os efeitos de verdade produzidos por esse poder, os quais, por sua vez, reconduzem novamente o próprio poder. Nas palavras de Foucault (2010, p. 21): "Portanto, triângulo: poder, direito, verdade". Logo, em vez da discussão filosófica quanto aos limites do poder, Foucault se preocupa mais com a questão factual de se perquirir quais seriam as regras de direito de que se valem as relações de poder para produzir discursos de verdade. Deste modo, reconhecese que o exercício do poder não pode funcionar sem uma certa economia dos discursos de verdade, de modo que "Somos submetidos pelo poder à produção da verdade e só podemos exercer o poder mediante a produção de verdade" (FOUCAULT, 2010, p. 22).

Para o autor, se existe algum poder, este somente pode ocorrer a partir e por meio dos discursos, verdadeiro campo de luta, ${ }^{4}$ lugar de uma profunda inquietação (FOUCAULT, 2014a, p. 7-8). ${ }^{5}$ No que tange ao problema do discurso, Foucault (2014a,

por Foucault: “A nosso ver, esse eixo não está representado nem pelo saber, nem pelo poder, nem pelo sujeito, mas pela maneira em que eles se correlacionam. Para ter acesso a esse eixo, Foucault teve, primeiro, de fazer perder a cada uma dessas noções o caráter substancial que frequentemente se lhes atribuía. O saber, o poder ou o sujeito só existem no plural e sem nenhuma identidade que transcenda suas múltiplas formas históricas. Por essa razão, para expressar a pluralidade histórica de cada um deles, em seu último curso no Collège de France, Foucault não fala de saber, mas de modos de veridicção, não fala de poder, mas de técnicas de governamentalidade e não fala de sujeito, mas de práticas de si” (CASTRO, 2014, p. 75).

4 Pois, conforme escreve Foucault (2014a, p. 10): “[...] e visto que - isto a história não cessa de nos ensinar o discurso não é simplesmente aquilo que traduz as lutas ou os sistemas de dominação, mas aquilo porque, pelo que se luta, o poder do qual nos queremos apoderar".

5 Uma profunda inquietação, como posto por Foucault (2014a, p. 7-8) em sua aula inaugural no Collège de France, A ordem do discurso: "Mas pode ser que essa instituição e esse desejo não sejam outra coisa 
p. 14-17) escreve em $A$ ordem do discurso que a razão do discurso, primeiramente regida por uma verdade baseada no ato ritualizado, eficaz e justo de enunciação, vai passar, no que Foucault designa como a marca de uma divisão histórica que deu forma geral à nossa vontade de saber, para o próprio enunciado, em seu sentido, sua forma, seu objeto e sua referência. Essa marca, exemplificada na divisão estabelecida entre Hesíodo e Platão (no sentido do estabelecimento de uma divisão que separa o discurso verdadeiro e o falso), não cessará de se deslocar, de modo que com as grandes mutações científicas, foram aparecendo novas formas de vontade de verdade. Essas novas formas de vontade de verdade, muito diferentes das anteriores, assim como outros sistemas de exclusão, terão um suporte institucional, sendo ao mesmo tempo reforçadas e reconduzidas por uma espessa gama de práticas. Deste modo, diz o autor:

Enfim, creio que essa vontade de verdade assim apoiada sobre um suporte e uma distribuição institucional, tende a exercer sobre os outros discursos - estou sempre falando de nossa sociedade - uma espécie de pressão e como que um poder de coerção. Penso na maneira como a literatura ocidental teve de buscar apoio, durante séculos, no natural, no verossímil, na sinceridade, na ciência também - em suma, no discurso verdadeiro. Penso, igualmente, na maneira como as práticas econômicas, codificadas como preceitos ou receitas, eventualmente como moral, procuraram, desde o século XVI, fundamentar-se, racionalizar-se e justificar-se a partir de uma teoria das riquezas e da produção; penso ainda na maneira como um conjunto tão prescritivo quanto o sistema penal procurou seus suportes ou sua justificação, primeiro, é certo, em uma teoria do direito, depois, a partir do século XIX, em um saber sociológico, psicológico, médico, psiquiátrico: como se a própria palavra da lei não pudesse mais ser autorizada, em nossa sociedade, senão por um discurso de verdade (FOUCAULT, 2014a, p. 17-18).

Desta forma, o que por ora se quer salientar, é que Foucault (2010, p. 30) se propõe a analisar o poder, em sua inovadora abordagem, não na perspectiva da soberania jurídica, nem pela instituição do Estado, mas a partir do âmbito das técnicas e táticas de dominação. ${ }^{6}$ Nesse sentido, propunha que o poder deveria ser analisado pelos seus

senão duas réplicas opostas a uma mesma inquietação: inquietação diante do que é o discurso em sua realidade material de coisa pronunciada ou escrita; inquietação diante dessa existência transitória destinada a se apagar sem dúvida, mas segundo uma duração que não nos pertence; inquietação de sentir sob essa atividade, todavia cotidiana e cinzenta, poderes e perigos que mal se imagina; inquietação de supor lutas, vitórias, ferimentos, dominações, servidões, através de tantas palavras cujo uso há tanto tempo reduziu as asperidades".

6 De modo exemplar, vale menção as seguintes afirmações do autor: "Para resumir essas cinco precauções de método, eu diria isto: em vez de orientar a pesquisa sobre o poder para o âmbito do edifício jurídico da 
mecanismos gerais ou efeitos de conjunto, tratando-se de se analisar suas extremidades, em seus últimos lineamentos, nos quais se torna capilar. Tratar-se-ia, então, de analisar o poder como algo que circula, algo que só funciona em cadeia, que funciona de modo transitivo pelos indivíduos, de modo que "O indivíduo é um efeito do poder e é, ao mesmo tempo, na mesma medida em que é um efeito seu, seu intermediário: o poder transita pelo indivíduo que ele constituiu" (FOUCAULT, 2010, p. 26).

Isso interessa sobremaneira para a presente discussão, pois ao tratar do fenômeno biopolitico Foucault seguirá uma abordagem corolária daquela feita em relação ao poder, de modo que principiará suas análises a partir da teoria da soberania, para então chegar às minúcias do funcionamento da biopolítica na contemporaneidade, quase como que por uma espécie de especificação. Trata-se, portanto, primeiro da teoria da soberania, ${ }^{7}$ a qual na sua acepção clássica tinha como insígnia a atribuição ao soberano de um dos seus mais característicos privilégios e fundamentais atributos: o exercício do poder essencialmente como um direito de vida e morte sobre seus súditos, como escreve Foucault (2010, p. 202) em Em defesa da sociedade:

O efeito do poder soberano sobre a vida só se exerce a partir do momento em que o soberano pode matar. Em última análise, o direito de matar é que detém efetivamente em si a própria essência desse direito de vida e de morte: é porque o soberano pode matar que ele exerce seu direito sobre a vida. É essencialmente um direito de espada. Não há, pois, simetria real nesse direito de vida e de morte. Não é o direito de fazer morrer ou de fazer viver. Nem é tampouco o direito de deixar viver e de deixar morrer. É o direito de fazer morrer ou de deixar viver. O que, é claro, introduz uma dissimetria flagrante.

Este direito, sem dúvida, derivava formalmente da velha patria potestas, a qual concedia ao pai de família romano o direito de disposição da vida de seus filhos e de seus escravos. Na sua formulação pelos teóricos clássicos, o direito de vida e de morte aparece como uma forma atenuada desse poder, o qual, todavia, não se admitia que fosse exercido de modo absoluto e incondicional, mas apenas nos casos em que o soberano

soberania, para o âmbito dos aparelhos de Estado, para o âmbito das ideologias que o acompanham, creio que se deve orientar a análise do poder para o âmbito da dominação (e não da soberania), para o âmbito dos operadores materiais, para o âmbito das formas de sujeição, para o âmbito das conexões e utilizações dos sistemas locais dessa sujeição e para o âmbito, enfim, dos dispositivos de saber" (FOUCAULT, 2010, p. 30).

7 Pois, conforme explica Foucault (2017, p. 97), neste primeiro momento, no pensamento e na análise política, “ainda não cortaram a cabeça do rei”. Disto resulta a importância que ainda se dá, na teoria do poder, ao problema do direito e da violência, da lei e da ilegalidade, da vontade e da liberdade, e, sobretudo, do Estado e da soberania, pois tais questões eram pensadas a partir de uma forma histórica bem particular às nossas sociedades, qual seja, a monarquia jurídica. 
se encontrasse exposto e ameaçado em sua própria existência, algo como um direito de réplica. Assim, teria o soberano um direito direto e indireto de vida e morte sobre seus súditos: indireto nos casos em que o soberano fosse ameaçado por inimigos externos e convocasse seus súditos para defenderem o Estado; direto nos casos em que são os próprios súditos que se insurgem contra o soberano e infringem suas leis (FOUCAULT, 2017, p. 145).

Esse direito, conforme escreve Foucault (2017, p. 146), era um direito caracteristicamente assimétrico, tanto em sua forma moderna, relativa e limitada, quanto em sua forma antiga, absoluta. Assim, tendo em vista que só exerce seu poder sobre a vida e a morte aquele que tem condições de exigi-la, é exercendo seu direito de matar que o soberano exerce seu direito sobre a vida. Nestes termos, "O direito que é formulado como 'de vida e morte' é, de fato, o direito de causar a morte ou de deixar viver" (FOUCAULT, 2017, p. 146). De acordo com o autor, esse direito era, afinal, simbolizado pelo gládio, e funcionava essencialmente como instância de confisco: de bens, produtos, serviços, trabalho e mesmo o sangue, de modo que nessa sociedade o poder era, antes de tudo, " [.... direito de apreensão das coisas, do tempo, dos corpos e, finalmente, da vida; culminava com o privilégio de se apoderar da vida para suprimi-la" (FOUCAULT, 2017, p. 146).

Contudo, a partir da época clássica os mecanismos de poder conhecem uma transformação profunda no Ocidente. Para Foucault (2017, p. 146), o poder vai deixar de ser exercido tão somente como instância de "confisco", passando esta função a ser uma peça dentre outras, às quais se somam outras funções, como as de controle, incitação, reforço, vigilância, majoração e organização das forças que lhes são submetidas. Deste modo, o direito de morte irá se deslocar e se apoiar nas exigências de um poder que gere a vida e se ordena em função das suas necessidades, ocupando-se muito mais em produzir, estimular e ordenar forças do que barrá-las, dobrá-las ou destruí-las, o que permite ao autor afirmar que o velho direito de causar a morte ou deixar viver foi substituído, ou, melhor dizendo, complementado, por um poder de causar a vida ou devolver à morte (FOUCAULT, 2017, p. 149).

Este poder, de causar a vida ou devolver à morte, se desenvolveu concretamente a partir do século XVII, e em duas formas diferentes, as quais não só não se contradizem, como, em verdade, se complementam de modo indissociável. ${ }^{8}$ Consoante Foucault (2017, p. 150), as duas formas seriam as seguintes:

\footnotetext{
8 Nesse sentido, as palavras de Edgardo Castro (2014, p. 104): "Pois bem, essa nova forma de exercício do poder se desenvolve em duas direções diferentes e complementares. Por um lado, uma 'anatomopolítica do corpo humano': as disciplinas, a normalização do corpo dos indivíduos. Por outro, 'uma biopolítica das populações': a normalização de sua vida biológica. A primeira, anatômica e individualizante, toma forma a partir do século XVII e a segunda, biológica e orientada à espécie, mais tarde, desde meados do século XVIII. A sociedade moderna normalizadora é, nessa perspectiva, 'o efeito de uma tecnologia de poder 
Um dos polos, o primeiro a ser formado, ao que parece, centrou-se no corpo como máquina: no seu adestramento, na ampliação de suas aptidões, na extorsão de suas forças, no crescimento paralelo de sua utilidade e docilidade, na sua integração em sistemas de controle eficazes e econômicos - tudo isso assegurado por procedimentos de poder caracterizam as disciplinas: anátomo politica do corpo humano. O segundo, que se formou um pouco mais tarde, por volta da metade do século XVIII, centrou-se no corpoespécie, no corpo trespassado pela mecânica do ser vivo e com suporte dos processos biológicos: a proliferação, os nascimentos e a mortalidade, o nível de saúde, a duração da vida, a longevidade, com todas as condições que podem fazê-los variar; tais processos são assumidos mediante toda uma série de intervenções e controles reguladores: uma biopolítica da população.

A primeira forma de poder, representada principalmente pelo poder disciplinar, tinha como principal insígnia o panóptico de Jeremy Bentham. Este poder, deve-se dizer, é calcado nesses "[...] métodos que permitem o controle minucioso das operações do corpo, que realizam a sujeição constante de suas forças e lhes impõe uma relação de docilidade-utilidade, são o que podemos chamar 'as disciplinas"' (FOUCAULT, 2014b, p. 135). A partir delas forma-se uma "microfísica do poder", a qual funciona no sentido de se dominar os corpos dos outros de tal maneira que façam não somente o que se quer, mas também do modo que se quer, com as técnicas designadas, conforme a eficácia e rapidez exigidas. Deste modo, diz Foucault (2014b, p. 135-136) que "A disciplina aumenta as forças do corpo (em termos econômicos de utilidade) e diminui essas mesmas forças (em termos políticos de obediência)". ${ }^{9}$

A biopolítica, ${ }^{10}$ por sua vez, como escreve Foucault (2008, p. 3) no curso Segurança, território, população, vai ser centrada não mais no homem-corpo, mas

centrada na vida'. A importância da sexualidade reside em que ela se situa no cruzamento entre a dimensão das disciplinas e a biopolítica e, desse modo, permite articular os dois eixos do biopoder".

9 É oportuno salientar, neste momento, que este mecanismo de poder baseado no Panóptico tem como uma de suas maiores características o fato ser uma tecnologia política polivalente, a qual pode se destacar de qualquer uso específico. Nesse sentido, ela "[...] serve para emendar os prisioneiros, guardar os loucos, fiscalizar os operários, fazer trabalhar os mendigos e ociosos. É um tipo de implantação dos corpos no espaço, de distribuição dos indivíduos em relação mútua, de organização hierárquica, de disposição dos centros e dos canais de poder, de definição de seus instrumentos e modos de intervenção, que se podem utilizar nos hospitais, nas oficinas, nas escolas, nas prisões. Cada vez que se tratar de uma multiplicidade de indivíduos a que se deve impor uma tarefa ou um comportamento, o esquema do panóptico poderá ser utilizado" (FOUCAULT, 2014b, p. 199).

10 Vale observar que a primeira vez na qual Foucault utilizou a expressão "biopolítica" foi em um curso por ele dado na cidade do Rio de Janeiro, sobre a história da medicina, intitulado "O nascimento da medicina social”. Nesse curso ele utiliza pela primeira vez o termo (biopolítica) para se referir, no contexto da história política moderna, ao momento no qual a vida biológica da população se inscreve nos cálculos do Estado 
no homem-espécie, isto é, ela envolverá toda uma série de fenômenos e conjuntos de mecanismos pelos quais aquilo que, na espécie humana, constituem suas características biológicas fundamentais e que, então, passam a fazer parte da estratégia política, da estratégia geral de poder. De modo resumido, o que o autor chama de biopoder é "Em outras palavras, como a sociedade, as sociedades ocidentais modernas, a partir do século XVIII, voltaram a levar em conta o fato biológico fundamental de que o ser humano constitui uma espécie humana" (FOUCAULT, 2008, p. 3). Como consequência, a biopolítica vai tratar principalmente dos problemas relacionados à natalidade, à mortalidade e à longevidade, os quais estão ligados a uma série de problemas econômicos e políticos que surgiram na segunda metade do século XVIII, e se tornaram, assim, os primeiros objetos de saber e alvos de controle dessa biopolítica (FOUCAULT, 2010, p. 204).

E aqui Foucault denota outra diferença importante: enquanto no âmbito do poder disciplinar se estava a lidar com uma tecnologia do indivíduo-corpo, no reino da biopolítica, diferentemente, está-se lidando com um novo corpo, um corpo múltiplo, com inúmeras cabeças, que se traduz na noção de "população". Assim, pode-se constatar que "A biopolítica lida com a população, e a população como problema político, como problema a um só tempo científico e político, como problema biológico e como problema de poder, [...] aparece nesse momento" (FOUCAULT, 2010, p. 206). Desta forma, a partir de tais distinções, pode-se mesmo falar, como Foucault anuncia já na última aula do curso Em defesa da sociedade, em duas séries, correspondentes a uma das "acomodações" realizadas pelas tecnologias do poder disciplinar e do biopoder: respectivamente, a série "corpo - organismo - disciplina - instituições" e a série "população - processos biológicos - mecanismos reguladores - Estado" (FONSECA, 2012, p. 207).

Este poder novo, o biopoder, portanto, vai levar em conta este novo personagem político que aparece no contexto do fenômeno da cidade, a população. E, embora esta não seja uma novidade absoluta na história do pensamento político, o que surge de fato como novidade, é a forma que a população toma no contexto dos dispositivos de segurança ${ }^{11}$ (CASTRO, 2014, p. 112). Desta forma, consoante Edgardo Castro (2014, p. 112), no biopoder a população vai aparecer, por um lado, “em sua dimensão biológica, em sua naturalidade: suas variações em relação ao clima e à geografia, suas

(CASTRO, 2014, p. 52).

11 Quanto aos dispositivos de segurança, vale o seguinte esclarecimento: conforme a nota do editor presente no curso Segurança, território, população (FOUCAULT, 2008, p. 32), é na última aula (17 de março de 1976) do curso Em defesa da sociedade o momento no qual Foucault distingue pela primeira vez os mecanismos de segurança dos mecanismos disciplinares. Deve-se notar, então, que o conceito de "segurança", utilizado em Segurança, território e população, não foi retomado no primeiro volume da História da sexualidade, $A$ vontade de saber, pois nesta obra Foucault prefere, em oposição às disciplinas, as quais são exercidas sobre o corpo dos indivíduos, o conceito de "controles reguladores", que são os dispositivos encarregados da saúde e da vida das populações. 
taxas de crescimento e mortalidade, os desejos que movem seus comportamentos, etc.", e, por outro, “em sua dimensão pública: as opiniões, os comportamentos, os hábitos, as convicções, etc.". ${ }^{12}$

Em suma, pode-se dizer que Foucault opera de duas maneiras distintas: primeiro, a partir do que ele chama de uma "analítica do poder", por meio da qual ele procede à refutação das principais versões de um modelo que se poderia chamar de "substancial" ou "essencialista" do poder; em um segundo momento, a esse poder, que Foucault também denomina de "jurídico-discursivo", se oporia o modelo da normalização, modelo no qual o poder será pensado enquanto estratégia. O ponto de chegada comum destas críticas é que teriam servido de abertura para as análises acerca desta outra face do mecanismo de normalização, a dos mecanismos de regulação da biopolítica e, em seguida, os dispositivos de segurança (FONSECA, 2012, p. 190-191). Todavia, há a necessidade de fazer aqui um importante esclarecimento. Foucault deixa bem claro que não se trata de uma identificação entre determinadas épocas históricas e seus respectivos dispositivos de poder, como se houvesse uma época arcaica, regida pelo dispositivo da soberania, outra moderna, sob a égide do dispositivo das disciplinas e uma contemporânea, pelos dispositivos da segurança e da biopolítica. Em verdade, não há uma sucessão destes dispositivos, mas sim uma simultaneidade (CASTRO, 2014, p. 110).

Foucault (2008, p. 8-9) descreve pormenorizadamente, no curso Segurança, território, população, o funcionamento e as características de três mecanismos, ou dispositivos, de poder: o mecanismo legal ou jurídico, o mecanismo disciplinar e o dispositivo de segurança. O primeiro, o mecanismo jurídico, ${ }^{13}$ consiste em criar uma lei e estabelecer uma punição para os que a infringirem, é o sistema do código legal, que funciona com a divisão binária entre o permitido e o proibido e o seu acoplamento a um tipo de punição; o segundo, o mecanismo disciplinar, ${ }^{14}$ é aquele no qual a lei é enquadrada

12 À maneira de exemplo, Foucault (2008, p. 83) cita três problemas ligados especificamente ao aparecimento do fenômeno das cidades: a própria cidade, a escassez alimentar e a epidemia (ou, a rua, o cereal e o contágio): "Esses três fenômenos, vemos imediatamente que têm entre si um vínculo bem visível, muito manifesto: todos estão ligados ao fenômeno da cidade. Todos eles se encaixam portanto no primeiro dos problemas que procurei esboçar, porque afinal de contas o problema da escassez alimentar e do cereal é o problema da cidade-mercado, o problema do contágio e das doenças epidêmicas, é o problema da cidade como foco de doenças. A cidade como mercado também é a cidade como lugar de revolta; a cidade, foco de doenças, é a cidade como lugar de miasmas e de morte. De qualquer modo, o problema da cidade é que está, acredito, no âmago desses diferentes exemplos de mecanismo de segurança".

13 Como diz Foucault (2017, p. 93-94) em A vontade de saber: "Essa forma é o direito, com o jogo entre o lícito e o ilícito, a transgressão e o castigo", e, mais à frente, "[...] porque é um poder que só teria a potência do 'não' incapacitado para produzir, apto apenas a colocar limites, seria essencialmente antienergia; esse seria o paradoxo de sua eficácia: nada poder, a não ser levar aquele que sujeita a não fazer senão o que lhe permite. Enfim, porque é um poder cujo modelo seria essencialmente jurídico, centrado exclusivamente no enunciado da lei e no funcionamento da interdição".

14 Em Vigiar e punir: "Forma-se então uma política das coerções que são um trabalho sobre o corpo, uma 
por mecanismos de vigilância e de correção, no qual vai aparecer um terceiro personagem, o culpado, que surge simultaneamente dentro e fora do sistema binário do código (dentro, com o ato legislativo que cria a lei e o ato judicial que pune o culpado, mas também fora, pois para o culpado aparecerá também toda uma série de técnicas adjacentes, policiais, médicas, psicológicas, que são do domínio da vigilância, do diagnóstico, da eventual transformação dos indivíduos); e, enfim, a terceira forma, a dos dispositivos de segurança (ou mecanismos reguladores), ${ }^{15}$ os quais inserirão os fenômenos do seu interesse numa série de acontecimentos prováveis, inseridas num cálculo de custo e, em vez do sistema do código binário (permitido/proibido), este vai fixar, de um lado, uma média considerada ótima para depois, então, estabelecer os limites do aceitável, além dos quais não se poderia ir (ou seja, envolve previsão, cálculo e controle de custos).

Não há, portanto, uma série de elementos que se sucedem, como se os elementos mais novos implicassem no desaparecimento dos antecedentes. Não há a era do legal, a era do disciplinar e a era da segurança. Os mecanismos de segurança não tomaram o lugar das disciplinas, que, por sua vez, teriam tomado o lugar dos mecanismos jurídico-legais. O que se sucede, em verdade, de acordo com Foucault (2008, p. 11), é a ocorrência de uma série de edifícios complexos, nos quais o que irá se alterar será principalmente qual é o mecanismo dominante, ou, para ser mais exato, o que se altera é o sistema de correlação entre os mecanismos jurídico-legais, os mecanismos disciplinares e os mecanismos de segurança.

É deste modo, vale observar, a partir da análise dos dispositivos de segurança e da problemática moderna da população, que Foucault será conduzido até a questão do governo e da governamentalidade,${ }^{16}$ que Foucault (2008, p. 143) assim define:

manipulação calculada de seus elementos, de seus gestos de seus comportamentos. O corpo humano entra numa maquinaria de poder que o esquadrinha, o desarticula e o recompõe. Uma 'anatomia política', que é também igualmente uma 'mecânica do poder', está nascendo; ela define como se pode ter domínio sobre o corpo dos outros, não simplesmente para que façam o que se quer, mas para que operem como se quer, com as técnicas, segundo a rapidez e a eficácia que se determina. A disciplina fabrica assim corpos submissos e exercitados, corpos 'dóceis"” (FOUCAULT, 2014b, p. 135).

15 De modo a exemplificar os dispositivos de segurança, segue o comentário de Giorgio Agamben (2014): "Um dos principais problemas que os governos então precisavam enfrentar era o da escassez de alimento e a fome. Até Quesnay, eles tentavam preveni-los criando celeiros públicos e proibindo a exportação de grãos. Mas essas medidas preventivas tinham efeitos negativos sobre a produção. A ideia de Quesnay foi inverter o procedimento: em vez de tentar prevenir a fome, era preciso deixa-la acontecer e, pela liberação do comércio exterior e interior, governá-la quando ocorresse. 'Governar' retoma aqui seu sentido etimológico: um bom piloto - aquele que detém o governo - não pode evitar a tempestade, mas, se ela ocorre, ele deve ser capaz de dirigir seu barco".

16 Vale ressaltar, neste ponto, a inovadora perspectiva com a qual Foucault (2008, p. 144-145) se propõe a analisar o Estado: “[...] o Estado, sem dúvida, não mais hoje em dia do que no curso da sua história, nunca teve essa unidade, essa individualidade, essa funcionalidade rigorosa e, diria até, essa importância. Afinal de contas, o Estado talvez não seja mais que uma realidade compósita e uma abstração mitificada cuja importância é bem mais reduzida que se imagina. Talvez. O que há de importante para a nossa modernidade, 
Por esta palavra, "governamentalidade", entendo o conjunto constituído pelas instituições, os procedimentos, análises e reflexões, os cálculos e as táticas que permitem exercer essa forma bem específica, embora muito complexa, de poder que tem por alvo principal a população, por principal forma de saber a economia política e por instrumento técnico essencial os dispositivos de segurança.

Como se pode notar, a governamentalidade tem por objetivo traduzir justamente esta nova mentalidade, esta nova forma de governar, que se dá com a derrocada da forma de gestão centrada no modelo da soberania e a entrada no governo "econômico" dos homens e das coisas, devido a emergência do fenômeno da população (FOUCAULT, 2008, p. 127-142). A governamentalidade, ${ }^{17}$ para Foucault, apesar de ser um fenômeno tortuoso, por terem seus problemas, bem como as técnicas de governo, tornados o único intuito e espaço real dos embates políticos, apesar disso, foi este o fenômeno que permitiu ao Estado sobreviver. Pois foi devido à governamentalidade que o Estado, como o conhecemos, permitiu-se definir o que deve ser do âmbito do Estado e o que não deve, o que deve ser público e o que deve ser privado, o que é estatal e o que não é, de modo que, "Portanto, se quiserem, o Estado em sua sobrevivência e o Estado em seus limites só devem ser compreendidos a partir das táticas gerais da governamentalidade" (FOUCAULT, 2008, p. 145).

Para uma continuidade das pesquisas relacionadas à governamentalidade, ${ }^{18}$ deve-se fazer referência a Giorgio Agamben, o qual, seguindo os traços deixados por Foucault, promoveu um empreendimento genealógico muito profícuo em sua obra $\mathrm{Il}$ regno e la gloria. Per uma genealogia teológica dell'economia e del governo. ${ }^{19}$ Todavia,

isto é, para a nossa atualidade, não é portanto a estatização da sociedade, mas o que eu chamaria de 'governamentalização' do Estado'.

17 A qual, conforme Foucault (2008, p. 219), nasce a partir do poder pastoral e que está umbilicalmente ligada ao nascimento também do Estado Moderno: "Em suma, o pastorado não coincide nem com uma política, nem com uma retórica. É uma coisa inteiramente diferente. É uma arte de governar os homens, e é por aí, creio, que devemos procurar a origem, o ponto de formação, de cristalização, o ponto embrionário dessa governamentalidade cuja entrada na política assinala, em fins do século XVI, séculos XVII-XVIII, o limiar do Estado moderno. O Estado moderno nasce, a meu ver, quando a governamentalidade se torna efetivamente uma prática política calculada e refletida".

18 De acordo com Agamben (2011, p. 125), em O reino e a glória, “o problema político essencial do nosso tempo": "O nascimento do estado de população e o primado dos dispositivos de segurança coincidem assim com o relativo declínio da função soberana e com a emergência no primeiro plano daquela governamentalidade que define o problema político essencial do nosso tempo".

19 Conforme propõe Agamben (2011, p. 9) no início de seu livro: "Esta pesquisa propõe-se a investigar os modos e os motivos pelos quais o poder foi assumindo no Ocidente a forma de uma oikonomia, ou seja, de um governo dos homens. Situa-se, portanto, no rastro das pesquisas de Michel Foucault sobre a genealogia da governamentalidade, mas procura, ao mesmo tempo, compreender as razões internas por que elas não chegaram a seu cumprimento. A sombra que a interrogação teórica do presente projeta sobre o passado alcança aqui, de fato, muito além dos limites cronológicos que Foucault atribuiu à sua genealogia, os 
não nos deteremos nesta obra, pois esse exercício excederia o âmbito e os limites dos fenômenos que estão no centro do presente ensaio. Nesse sentido, retorna-se agora à questão da biopolítica, especialmente levando em consideração as contribuições dadas por Agamben quanto a este tema na obra "Homo sacer - Il potere sovrano e la nuda vita I'.

Agamben: biopolítica, poder soberano e vida nua

A biopolítica é, sem dúvida, um dos temas mais caros a Giorgio Agamben, especialmente a biopolítica no século XX. Nesse sentido, de acordo com Agamben, Foucault, devido à sua morte, não teve a oportunidade de desenvolver todas as implicações do conceito de biopolítica, como também, por outro lado, não se poderia dizer, afinal, em qual sentido suas pesquisas teriam seguido,

[...] mas, em todo caso, o ingresso da zoé na esfera da pólis, a politização da vida nua como tal constitui o evento decisivo da modernidade, que assinala uma transformação radical das categorias político-filosóficas do pensamento clássico. É provável, aliás, que, se a política parece hoje atravessar um duradouro eclipse, isto se dê precisamente porque ela eximiu-se de um confronto com este evento fundador da modernidade (AGAMBEN, 2010a, p. 12).

A abordagem tomada por Foucault, segundo Agamben, teria deixado uma questão sem resposta, que seria saber qual o ponto de conversão entre estes dois aspectos do poder por ele delineados: isto é, as técnicas de individualização subjetivas e os procedimentos de totalização objetivos, em relação aos quais Foucault afirmava haver um "genuíno duplo vínculo político, constituído pela individuação e pela simultânea totalização das estruturas do poder moderno" (AGAMBEN, 2010a, p. 13).

Em outras palavras, Agamben (2010a, p. 13) está a se indagar a seguinte questão: “onde está, então, no corpo do poder, a zona de indiferenciação (ou, ao menos, o ponto de intersecção) em que técnicas de individualização e procedimentos totalizantes se tocam?". Encontrar a resposta para esta pergunta seria exatamente um dos objetivos que o filósofo italiano teria imposto a si mesmo. Nesse sentido, referindo-se ao primeiro volume

primeiros séculos da teologia cristã, que viram a primeira e incerta elaboração da doutrina trinitária na forma de uma oikonomia. Situar o governo em seu locus teológico na oikonomia trinitária não significa tentar explica-los através de uma hierarquia das causas, como se à teologia coubesse necessariamente um papel genético mais originário; significa, ao contrário, mostrar de que maneira o dispositivo da oikonomia trinitária pode construir um laboratório privilegiado para observar o funcionamento e a articulação ao mesmo tempo interna e externa - da máquina governamental. E isso se deve ao fato de que nele os instrumentos - ou as polaridades - com que se articula a máquina aparecem, por assim dizer, em sua forma paradigmática". 
do Homo sacer, Agamben (2010a, p. 14) afirma que "A presente pesquisa concerne precisamente este oculto ponto de intersecção entre o modelo jurídico-institucional e o modelo biopolítico do poder", de modo que

O que ela teve de registrar entre os seus prováveis resultados é precisamente que as duas análises não podem ser separadas e que a implicação da vida nua na esfera política constitui o núcleo originário - ainda que encoberto - do poder soberano. Pode-se dizer, aliás, que a produção de um corpo biopolítico seja a contribuição original do poder soberano. A biopolítica é, nesse sentido, pelo menos tão antiga quanto a exceção soberana. Colocando a vida biológica no centro dos seus cálculos, o Estado moderno não faz mais, portanto, do que reconduzir à luz o vínculo secreto que une o poder à vida nua, reatando assim (segundo uma tenaz correspondência entre moderno e arcaico que nos é dado verificar nos âmbitos mais diversos) com o mais imemorial dos arcana imperii (AGAMBEN, 2010a, p. 14).

Como se pode notar, Agamben faz coro às preocupações de Foucault quanto à biopolítica. Com efeito, para o autor, somente em um horizonte biopolítico será possível decidir se as tradicionais categorias sobre cujas oposições a política moderna se fundou, e que foram progressivamente esfumando-se ao ponto de se tornarem indiscerníveis (como as oposições entre direita/esquerda, privado/público, absolutismo/democracia), deverão ser abandonadas de maneira definitiva ou se poderão ainda eventualmente reencontrar o significado que, naquele próprio horizonte, já haviam perdido (AGAMBEN, 2010a, p. 12).

Contudo, para Agamben, diferentemente da concepção de Foucault, o fato decisivo, o "evento decisivo da modernidade", não seria somente o advento da biopolítica, mas o fenômeno da politização da vida nua, a qual resulta justamente da ação do poder soberano, sendo dele indissociável, de modo que Agamben pode mesmo dizer que $a$ produção do corpo biopolítico seja a contribuição original do poder soberano. Esta é razão pela qual Agamben irá se concentrar, ao analisar a biopolítica, nos nexos existentes entre vida nua, poder soberano, estado de exceção e campo de concentração, categorias que perpassam toda a política ocidental, mas que encontraram, na modernidade, sua máxima saturação (DUARTE, 2008, p. 10).

Isso leva o autor, por sua vez, a indicar duas grandes "insuficiências teóricas": de um lado, Agamben (2010a, p. 11) aponta uma insuficiência em Foucault, que teria deixado de lado em suas escavações o local por excelência da biopolítica moderna, ou seja, a política dos grandes Estados totalitários do Novecentos, de modo que a sua pesquisa, que teria se iniciado com a reconstrução do "grand enfermement" nos hospitais e nas prisões, terminou por não se concluir com uma análise do campo de concentração; 
por outro, em Hannah Arendt, que vinte anos antes de Foucault já havia analisado em The Human condition (A Condição Humana) ${ }^{20}$ o processo que levou a vida biológica do homo laborans a ocupar progressivamente o centro da cena política do moderno - o que teria causado a transformação e a decadência do espaço público na sociedade moderna -, e, também, analisado a estrutura dos estados totalitários em Origins of totalitarianism (Origens do totalitarismo), mas que, todavia, em suas pesquisas, não abordou de nenhuma maneira a perspectiva biopolítica (AGAMBEN, 2010a, p. 116). Nesse sentido, é precisamente Agamben quem, com o seu projeto Homo sacer, se propõe a enfrentar as inconsistências, os pontos que teriam ficado sem resposta nos trabalhos de ambos os autores (CASTRO, 2013, p. 59), fazendo com que se produza, a partir de Homo sacer: o poder soberano e a vida nua $I$, o encontro entre estas duas potentes linhas de pensamento que até então não haviam se encontrado, isto é, o encontro entre Hannah Arendt e Michel Foucault (ASSMANN; BAZZANELLA, 2012, p. 63).

E o que permite a Agamben promover a conversão destes dois pontos de vista é justamente "la nuda vita", a vida nua. O conceito de vida nua, por sua vez, de acordo com Leland de la Durantaye (2009, p. 202-203), não é uma criação agambeniana, mas uma espécie de "citação sem aspas" que Agamben faz de Walter Benjamin. Ela aparece em Benjamin sob a sigla "das bloße Leben" ${ }^{21}$ (vida nua ou mera vida) nos ensaios Destino e caráter ${ }^{22}$ e Sobre a crítica do poder como violência, ${ }^{23}$ e que Agamben a conceba

20 Pois, como apontam Selvino José Assman e Sandro Luiz Bazzanella (2012, p. 74): “A leitura que Hannah Arendt faz ao longo de toda sua obra e, de forma mais específica, em A condição humana (1991), procura demonstrar como na modernidade política, a vita activa, presente entre os gregos foi suprassumida pelo trabalho e pelo labor nas sociedades de massas humanas atomizadas em processos de produção e de consumo. Tal fenômeno desdobra-se nas experiências totalitárias que o século XX vivenciou".

21 Quanto ao seu significado, de acordo com Leland de La Durantaye (2009, p. 203), "Although Benjamin does not offer further directions for how it is to be understood, it is clear that bare life is not an initial state so much as what becomes visible through a stripping away of predicates and attributes, and in this respect Geulen offers an excellent paraphrase when she notes that 'naked or bare (and bared) life is not a prior substance, but instead what remains after the withdrawal of all forms"'. Sobre este conceito valem menção também as palavras de Daniel Arruda Nascimento (2012, p. 110): "Benjamin usa a expressão bloße Leben. Leben traduz-se por vida. Bloss pode ser apenas, mera ou nua. As duas palavras conjugadas podem significar o simples fato de viver, ou sobreviver, ou o estado natural do ser humano".

22 Neste ensaio pode-se ler uma invocação da vida nua no contexto de uma discussão sobre a relação entre Direito e destino: "O Direito não condena à punição, mas à culpa. O destino é o contexto de culpa em que se inserem os vivos, e que corresponde à sua condição natural, aquela aparência ainda não completamente apagada de que o ser humano está tão afastado que nunca conseguiria mergulhar nela, limitando-se a permanecer invisível sob o seu domínio e apenas na sua melhor parte. Não é, portanto, afinal o ser humano que tem um destino: o sujeito do destino é indeterminável. O juiz pode descortinar o destino onde quiser, e ditará às cegas um destino com cada condenação. O ser humano nunca será atingido por esse destino, mas apenas a vida nua nele, que participa da culpa natural e da desgraça devido àquela aparência" (BENJAMIN, 2016, p. 53, grifo nosso).

23 "Por fim, dá que pensar o fato de que aquilo que aí se proclama como sagrado ser, de acordo com o antigo pensamento mítico, o suporte estigmatizado da culpa: a vida nua" (BENJAMIN, 2016, p. 81, grifo nosso). 
como "la nuda vita" não fica claro para o leitor, nem no seu ensaio de 1993, A Linguagem e a Morte, ${ }^{24}$ nem em nenhum outro ensaio, senão a partir da sua aparição no primeiro Homo sacer.

Em Homo sacer: o poder soberano e a vida nua I, publicado em 1995, obra que inicia o projeto Homo sacer, a vida nua aparece já na introdução da seguinte maneira: tendo como referência a definição aristotélica da pólis como oposição entre viver (zên) e viver bem (êu zên), Agamben (2010a, p. 14) se pergunta se esta “[...] oposição é, de fato, na mesma medida, uma implicação do primeiro no segundo, da vida nua na vida politicamente qualificada". A vida nua aparece, portanto, como um substitutivo para a palavra grega zoé, entendida pelo autor como o simples fato de viver, a qualidade de ser vivo, vida crua, vida no seu estado natural (NASCIMENTO, 2012, p. 169).

No entanto, deve-se observar que é somente no final da primeira parte do livro que a vida nua aparece melhor delineada, momento no qual Agamben (2010a, p. 70, grifo nosso) demonstra a correlação entre a sua formulação e a de Walter Benjamin: "Por isto não é por acaso que Benjamin, ao invés de definir a violência divina, num desdobramento aparentemente brusco prefira concentrar-se sobre o portador do nexo entre violência e direito, que ele chama de 'vida nua' (bloße Leben)". Ou seja, pode-se dizer, com Leland de la Durantaye (2009, p. 203), que

At the end of part one, however, Agamben turns to Benjamin's analyses of law and life and there underlines the relation of the one formulation to the other: "nuda vita (bloß Leben)". "Nuda vita" - naked or bare life - is thus, for Agamben, another way of saying bloße Leben - bare life.

Merece atenção, no entanto, o fato de que esta expressão apareça também em outros trabalhos do autor, os quais necessitam ser aqui citados: primeiro em $L a$ comunità che viene (A comunidade que vem), publicado pela primeira vez em 1990, e, em seguida, na coletânea Mezzi senza fine (Meios sem fim: notas sobre a política), publicada em 1996 (NASCIMENTO, 2012, p. 169). Em A comunidade que vem a vida nua aparece como a categoria em relação a qual o pequeno burguês "[...] se confronta com a última expropriação, com a última frustração da individualidade: a vida nua, o puro incomunicável, onde a sua vergonha encontra finalmente a paz” (AGAMBEN, 2013, p. 60), ou seja, a burguesia (no dizer de Agamben, "pequena burguesia planetária"), herdeira de um mundo desprovido de classes, tornada sociedade do espetáculo e do consumo, vazia, não escapa à constatação de estar ela mesma fadada à vida nua (NASCIMENTO,

\footnotetext{
24 "Até mesmo a sacralização da vida deriva, de fato, do sacrifício: ela nada faz, deste ponto de vista, além de abandonar a vida nua natural à própria violência e à própria indizibilidade, para fundar então sobre estas toda regulamentação cultural e toda linguagem" (AGAMBEN, 2006, p. 143, grifo nosso).
} 
2012, p. 169). Por sua vez, em Meios sem fim a vida nua aparece em duas ocasiões: primeiro, no capítulo "Forma-de-vida", como o aparato sob o qual o poder soberano se funda: "A puissance absolue et perpetuelle, que define o poder estatal, não se funda, em última instância, em uma vontade política, mas na vida nua, que é conservada e protegida somente na medida em que se submete ao direito de vida e morte do soberano (ou da lei)" (AGAMBEN, 2015a, p. 15); e, em seguida, no capítulo "Notas sobre a política", a vida nua aparece como aquilo que, "[tendo em vista] que o estado de exceção é a regra, que a vida nua é imediatamente portadora do nexo soberano [ou seja, portadora do nexo soberano que une violência e direito] e, como tal, ela é hoje abandonada a uma violência tanto mais eficaz quanto anônima e cotidiana" (AGAMBEN, 2015a, p. 104, parênteses nosso).

E por que se faz necessário ressaltar tais questões? A necessidade reside em duas importantes e distintivas razões: primeiro, porque é justamente pelo fato de que o "poder absoluto e perpétuo" do soberano ${ }^{25}$ não se funda, como se acreditava, na vontade política, mas na vida constantemente exposta à morte, a vida que somente adquire conservação e proteção na medida em que se submete ao poder de vida e morte do soberano, ou seja, na vida nua, que para Agamben o poder biopolítico não pode ser dissociado do poder soberano; em segundo lugar, porque isso demonstra o fato de que a biopolítica seria muito mais antiga do que se possa pensar, o que traduz uma essencial diferença entre a sua compreensão do termo em relação a de Foucault.

Nesse sentido, é muito diferente dizer, como o faz Foucault, que a biopolítica é um fenômeno relacionado ao nascimento do Estado moderno, com a sua racionalidade técnico-administrativa, que se impõe ao território e à população, do qual as origens remontam ao poder pastoral, característico do poder eclesiástico presente no mundo judaico-cristão medieval, de dizer, como o faz Agamben, que a biopolítica é um fenômeno intrínseco à experiência política ocidental desde os seus primórdios, ou seja, que ela é constitutiva da própria política ou das relações de poder político. Entende-se, deste modo, que para Agamben a biopolítica tem, com efeito, uma dimensão ontológica, enquanto que, para Foucault, não se poderia falar da biopolítica a não ser como experiência da política a partir do século XVIII. Esta seria a razão também pela qual, para Agamben, a biopolítica (fazer viver e deixar morrer) não pode ser desvinculada da teoria da soberania (fazer morrer e deixar viver), enquanto que, para Foucault, a teoria da soberania, embora

\footnotetext{
25 Conforme a clássica definição da soberania fornecida por Bodin: “[...] he gave a definition of sovereignty that must still be considered as fundamental today. After he formulated, in chapter 8 of Book I of his Six livres de la République, the definition of sovereignty that became so popular - 'la souveraineté est la puissance absolue et perpétuelle d'une République que les latins appellant maiestatem' ['sovereignty is the absolute and permanent kind of power of a republic that the Latins called majesty']" (SCHMITT, 2014, p. 20).
} 
seja contemporânea da biopolítica, pode ser claramente dela distinguida (ASSMANN; BAZZANELLA, 2012, p. 65). Fica demonstrada, desta maneira, a diferença essencial existente entre Foucault e Agamben, pois distintamente de Foucault, a biopolítica para Agamben não se refere apenas à modernidade, “....mas à própria tradição do pensamento político do ocidente, argumentando que a instituição do poder soberano é correlata à definição do corpo político em termos biopolíticos" (DUARTE, 2008, p. 11).

Além disso, deve-se ter em vista que se a implicação da vida nua na esfera política constitui o núcleo originário da política ocidental, isso significa dizer que a nossa política teve como evento decisivo a definição de uma exclusão: se se adotar como ponto de referência a definição aristotélica da pólis como oposição entre viver (zên) e viver bem (êै zên), a oposição se daria, de fato, como uma implicação do primeiro no segundo, ou seja, da vida nua na vida politicamente qualificada; no entanto, esta relação pode ser lida também "[...] como uma exclusão inclusiva (uma exceptio) da zoé na pólis, quase como se a política fosse o lugar em que o viver deve se transformar em viver bem, e aquilo que deve ser politizado fosse desde sempre a vida nua" (AGAMBEN, 2010a, p. 15).

Um dos objetivos de Homo sacer: o poder soberano e a vida nua I, era, afinal, precisamente proceder à análise das razões e consequências desta exclusão originária. ${ }^{26}$ Deste modo, faz-se coro à tese agambeniana de que “A 'politização' na vida nua é a tarefa metafísica por excelência", tendo em vista que o que a modernidade fez foi justamente adotar para si a estrutura essencial da tradição metafísica ocidental (AGAMBEN, 2010a, p. 15). Logo, conforme apontam Assmann e Bazzanella (2012, p. 73) é justamente por meio desta gênese antropológica e política da civilização ocidental que se confirma a tese que desde os primórdios civilizatórios a vida se torna objeto da política, "seja pela condição biológica da vida que lhe é limitante no acesso à vida qualificada na pólis", ou mesmo "em seu inverso, como vida qualificada, que se realiza no espaço por excelência da liberdade política da cidade". O que acontece, de qualquer maneira, é que esta perspectiva biopolítica se articula no decorrer da civilização ocidental, apresentando-se, na modernidade, a partir da precedência da vida biológica sobre a vida política.

Isto posto, deve-se agora partir para a análise de algumas consequências advindas da caracterização agambeniana sobre a biopolítica. Nesse sentido, na introdução do primeiro volume do Homo sacer, após expor a tese de que a implicação da vida nua na esfera política constituiria o núcleo originário, ainda que encoberto, do poder soberano,

26 Conforme observa Agamben (2015b, p. 20) em outra obra, também pertencente ao projeto homo sacer: "Questa opposizione di 'vivere' e 'vivere bene' è, però, nello stesso tempo una implicazione del primo nel secondo, della famiglia nella città e della zoé nel vita politica. Uno degli scopi di Homo sacer. Il potere sovrano e la nuda vita era appunto quello di analizzare le ragioni e le conseguenze di questa esclusione che è nello stesso tempo un'inclusione - della vita naturale nella politica". 
Agamben (2010a, p. 16) em seguida anuncia uma figura, o protagonista de seu livro: o portador da vida nua, a vida matável e insacrificável do homo sacer. ${ }^{27} \mathrm{O}$ homo sacer, conforme explica Agamben, era uma obscura figura do direito romano arcaico, o qual tinha sua vida humana incluída no ordenamento jurídico unicamente sob a forma da exclusão: estava excluído da lei humana por meio de sua absoluta matabilidade, pois seu assassínio não configurava homicídio; no entanto, encontrava-se excluído também da lei divina, pois o homo sacer não podia ser dado em sacrifício aos deuses. ${ }^{28}$

Desta forma, levando em consideração a figura do homo sacer, de acordo com Agamben (2010a, p. 16), a tese foucaultiana deverá ser então, se não corrigida, ao menos integrada, no sentido de que o que caracterizaria a política moderna não seria tanto a inclusão da zoé na pólis, como visto, em si já antiquíssima, nem simplesmente o fato de que a vida como tal venha a ser um objeto eminente dos cálculos e previsões do poder estatal (isto é, o advento da biopolítica e dos dispositivos de segurança). Para a política moderna, de acordo com Agamben (2010a, p. 16-17),

[...] decisivo é, sobretudo, o fato de que, lado a lado com o processo pelo qual a exceção se torna em todos os lugares a regra, o espaço da vida nua, situado originariamente à margem do ordenamento, vem progressivamente a coincidir com o espaço político, e exclusão e inclusão, externo e interno, bíos e zoé, direito e fato entram em uma zona de irredutível indistinção. $\mathrm{O}$ estado de exceção, no qual a vida nua era, ao mesmo tempo, excluída e capturada pelo ordenamento, constituía, na verdade, em seu apartamento, o fundamento oculto sobre o qual repousava o inteiro sistema político; quando as suas fronteiras se esfumam e se indeterminam, a vida nua que o habitava libera-se na cidade e torna-se simultaneamente o sujeito e o objeto do ordenamento político e de seus conflitos, o ponto comum tanto da organização do poder estatal quanto da emancipação dele. Tudo ocorre como se, no mesmo passo

27 "Early in Homo sacer Agamben announces that 'the protagonist of this book is bare life' (HS, 8 [II]). But what is 'bare life' and how has it been bared? Is it a good thing, such as a purification; a bad thing, such as a deprivation; or neither? Where do we glimpse this curious form of life, and what relation does it bear to the categories of creature and law? 'Bare life' is the translation given in Homo Sacer for la nuda vita" (DE LA DURANTAYE, 2009, p. 202).

28 Conforme aduz Agamben (2010a, p. 74), a memória do homo sacer chega até nós a partir de Festo, procurador romano da província da Judeia no século I, que no verbete sacer mons, do seu tratado Sobre o significado das palavras, nos conservou uma figura do direito romano arcaico no qual o caráter da sacralidade pela primeira vez se ligou a uma vida humana enquanto tal. E, de acordo com essa definição, "Homem sacro é, portanto, aquele que o povo julgou por um delito; e não é lícito sacrificá-lo, mas quem o mata não será condenado por homicídio; na verdade, na primeira lei tribunícia se adverte que 'se alguém matar aquele que por plebiscito é sacro, não será considerado homicida'. Disso advém que um homem malvado ou impuro costuma ser chamado sacro" (AGAMBEN, 2010a, p. 186). 
do processo disciplinar através do qual o poder estatal faz do homem enquanto vivente o próprio objeto específico, entrasse em movimento um outro processo, que coincide grosso modo com o nascimento da democracia moderna, no qual o homem como vivente se apresenta não mais como objeto, mas como sujeito do poder político. Estes processos, sob muitos aspectos opostos e (ao menos em aparência) em conflito acerbo entre eles, convergem, porém, no fato de que em ambos o que está em questão é a vida nua do cidadão, o novo corpo biopolítico da humanidade.

O que está em jogo na política moderna, portanto, como já foi afirmado, é a implicação da vida nua na esfera política. Implicação que está correlacionada à figura do homo sacer, o habitante de uma cinzenta zona de indiscernibilidade, ${ }^{29}$ a qual é produzida pelo poder soberano. Mas, afinal, o que representa o homo sacer e de que maneira esta aparentemente longínqua e arcaica categoria do direito romano pode nos afetar?

Para Agamben, a vida sagrada do homo sacer representa, acima de tudo, um conceito-limite do ordenamento social romano, que não pode, como tal, permanecer nem no interior do ius divinum nem do ius humanum, mas que pode, sim, ajudar a traçar uma luz quanto aos seus limites recíprocos. Desta forma, o autor se propõe a interpretar o homo sacer não calcado em uma pretensa ambiguidade originária do sagrado, ${ }^{30}$ que tem por base a noção de tabu (como diversos autores fizeram), mas sim como uma figura autônoma, a qual permite que se veja nele uma possível estrutura originária, que se encontra em uma zona anterior à própria distinção entre o sagrado e o profano, o religioso e o jurídico (AGAMBEN, 2010a, p. 76).

Assim, deve-se ter em conta, ao analisar esta questão, que a estrutura da sacratio (isto é, a sua sacralidade) a qual estava submetido o homo sacer é formada por dois aspectos: o impune occidi (a impunidade da matança) e o neque fas est eum immolari

29 “Homo sacer, essa 'enigmática figura do direito romano arcaico', é precisamente o nome que recebe a vida que, por sua correlação com o poder soberano, ingressou nessa zona de indistinção” (CASTRO, 2013, p. 60).

30 Ambiguidade esta que se encontra perfeitamente demonstrada a partir de uma breve consulta ao "Vocabulário das Instituições Indo-Europeias", de Émile Benveniste (1983, p. 350), obra frequentemente consultada por Agamben: "El término latino sacer encierra la representación que para nosotros es la más precisa y específica de lo 'sagrado'. Es en latín donde mejor se manifiesta la división entre lo profano y lo sagrado; es también en latín donde se descubre el carácter ambiguo de lo 'sagrado': consagrado a los dioses y cargado de una mancilla imborrable, augusto y maldito, digno de veneración y que suscita el horror. Este doble valor es proprio de sacer: contribuye a distinguir sacer y sanctus, porque no afecta en ningún grado al adjetivo emparentado sanctus". A própria confusa relação entre a sacralidade e o sacrificio é também por Benveniste (1983, p. 350) ressaltada: “Además, es la relación establecida entre sacer y sacrificare lo que nos permite comprender mejor el mecanismo de lo sagrado y la relación con el sacrificio. Este término de 'sacrificio', que nos es familiar, asocia una concepción y una operación que parecen no tener nada en común. Por qué 'sacrificar' quiere decir, de hecho, 'ejecutar', cuando propiamente significa 'hacer sagrado' (cfr. Sacrificium)?”. 
(a proibição da imolação, ou seja, a exclusão do sacrificio). Quanto ao primeiro aspecto, este indica uma exceção ao ius humanum, pois de acordo com ele estava suspendida a aplicação da lei sobre o homicídio. Por outro lado, também o segundo aspecto pode ser visto como uma exceção, mas neste caso em relação ao ius divinum e a toda e qualquer forma de morte ritual, pois as formas de execução capital, por mais terríveis que pudessem ser, significavam na realidade rituais de purificação, e não penas como as entendemos no sentido moderno. Deste modo, o que a proibição da imolação fazia, era servir como um critério de diferenciação, distinguindo a matança do homo sacer daquelas purificações rituais, excluindo, assim, decididamente a sacratio do âmbito religioso em sentido próprio (AGAMBEN, 2010a, p. 83).

No que tange ao ius divinum, foi observado que aquilo que faz normalmente passar um objeto da esfera humana para a divina é o rito da consecratio. ${ }^{31}$ Conforme aponta Agamben (2007, p. 65) em Profanazioni (Profanações), "consagrar (sacrare) era o termo que designava a saída das coisas da esfera do direito humano", sendo que "sagradas ou religiosas eram as coisas que de algum modo pertenciam aos deuses". E o dispositivo que realizava e regulava tal separação era precisamente o sacrifício: por meio da realização de uma série de rituais minuciosos, que variam de acordo com as culturas, o sacrifício estabelece, em todo caso, esta passagem de algo do profano para o sagrado, transladando-o da esfera humana para a divina (AGAMBEN, 2007, p. 65-66).

Separadas das coisas humanas, as coisas "sagradas" ficavam reservadas somente aos deuses, sendo que quem ultrapassasse ou violasse esta indisponibilidade praticava um sacrilégio. ${ }^{32}$ No entanto, não era isso que se passava com o homo sacer. Este era posto fora da esfera humana, sem, contudo, ultrapassar para a divina. Desta maneira, a proibição da imolação não somente exclui toda e qualquer equiparação do homo sacer a uma vítima consagrada, mas também a licitude da sua matança implica que a violência contra ele cometida não constitui também nenhum sacrilégio, como seria no caso das res sacrae (AGAMBEN, 2010a, p. 83-84). Logo, a partir destas considerações, pode-se dizer que o que a figura do homo sacer representa é mais do que uma simples exclusão, ela se mostra comportando uma estrutura simétrica à da sacratio, logo, algo mais, algo além de uma simples analogia àquela da exceção soberana:

31 Como escrevem Hubert e Mauss (2005, p. 15): "A palavra sugere imediatamente a ideia de consagração, e poder-se-ia pensar que as duas noções se confundem. Com efeito, é certo que o sacrifício sempre implica uma consagração: em todo sacrifício um objeto passa do domínio comum a domínio religioso - ele é consagrado".

32 E, conforme Agamben, (2007, p. 65), "Sacrílego era todo ato que violasse ou transgredisse esta sua especial indisponibilidade, que as reservava exclusivamente aos deuses celestes (nesse caso eram denominadas propriamente 'sagradas') ou infernais (nesse caso eram simplesmente chamadas 'religiosas')". 
Se isto é verdadeiro, a sacratio configura uma dupla exceção, tanto dos ius humanum quanto do ius divinum, tanto do âmbito religioso quanto do profano. A estrutura topológica, que esta dupla exceção desenha, é aquela de dúplice exclusão e de uma dúplice captura, que apresenta mais do que uma simples analogia com a estrutura da exceção soberana. [...] Assim como, na exceção soberana, a lei se aplica de fato ao caso excepcional desaplicando-se, retirando-se deste, do mesmo modo o homo sacer pertence ao Deus na forma da insacrificabilidade e é incluído na comunidade na forma da matabilidade. A vida insacrificável e, todavia, matável, é a vida sacra (AGAMBEN, 2010a, p. 84).

Pode-se afirmar, desta forma, que o que define o homo sacer para Agamben (2010a, p. 84) é, portanto, menos aquela pretensa ambivalência originária do sagrado que é possível nele observar, quanto, acima de tudo, o caráter de dupla exclusão ao qual se encontra preso e da violência sem precedentes à qual sua vida se encontra exposta, ${ }^{33}$ cuja condição pode ser resumida sob os termos de uma vida matável e, no entanto, insacrificável.

O homo sacer vive, portanto, nesta esfera limite de uma violência permanente: a sua absoluta matabilidade, afinal, não pode ser caracterizada nem como um homicídio nem como um sacrifício, nem como a execução de uma condenação nem como um sacrilégio. Desta forma, ele habita uma zona que foi isolada tanto das formas sancionadas pelo direito humano quanto pelo direito divino, o que faz surgir para ele uma esfera que não é nem a do agir humano nem a da ação divina (AGAMBEN, 2010a, p.

33 Quanto a este aspecto, é extremamente esclarecedor o que Rudolf von Jhering (1943, p. 201-202) tem a dizer sobre o homo sacer: "O homo sacer vivia em estado de proscrição religiosa e civil. Sujeito à vingança da divindade, a quem havia ultrajado com a sua má ação (sacer), e excluido, por consequência da comunidade humana, era privado de todos os seus bens em proveito dos deuses, podendo até ser morto pelo primeiro que assim o quizesse. Ser sacer era haver incorrido em uma pena? Ao nosso vêr, não. Certamente, se se entender por pena um mal que se segue à perpetração de um delito, tornar-se sacer era a pena mais grave que imaginar se póde, porque não há mal que esta situação não fizesse suportar; ela, de facto, constituia o último gráu da perseguição e da humilhação. Ao inimigo, também, se privava do direito; mas o que agravava a posição do homo sacer era o elemento psicológico, ou seja a convicção de ser para os deuses e para os homens objeto de maldição, de execreção e de aversão; um sêr nocivo, a quem se arremessava da comunidade dos homens às bestas féras, evitado por todos, podendo julgar-se feliz se se encontrava com alguem que não considerasse, como ato meritório, tirar-lhe a vida; em uma palavra, era o sentimento da maldição que sobre êle pesava, e o estigma da proscrição que tornava a sua posição tão miserável quanto possível. A pena, segundo a idéia originária anteriormente indicada, não sómente era um simples mal, mas tinha por fim purificar o delinquente, afim de reconciliá-lo com os deuses e os homens. No homo sacer, ao contrário, ainda que durasse a sua horrível situação por toda a vida, não conseguia nunca semelhante fim expiatório. Quem assim era maltratado, morria tal como vivia, homo sacer, irreconciliado com Deus e com os homens; a espada da justiça manchar-se-ia ao contacto de seu sangue, e como estava fóra do direito, a lei penal dêle não se ocupava. O estado do homo sacer não se podia definir de outro módo, ao nosso vêr, senão como o de um facínora, de um sacrílego, sem esperança de entrar na comunidade dos homens e da religião". 
84). Trata-se, em verdade, na criação de uma esfera-limite do agir humano que funciona unicamente em uma relação de exceção: "Esta esfera é a da decisão soberana, que suspende a lei no estado de exceção e assim implica nele a vida nua" (AGAMBEN, 2010a, p. 84).

Para Agamben (2010a, p. 26), a relação de exceção ${ }^{34}$ consiste na estrutura originária tanto da soberania quanto também da própria relação jurídica, pois é a partir da decisão soberana sobre a exceção - lembrando que para Agamben (2010a, p. 22) a estrutura da soberania é formada pelo que o autor denominou de "paradoxo da soberania", o qual consiste no fato de que soberano, responsável por decidir sobre o estado de exceção, consoante a clássica definição schmittiana, ${ }^{35}$ encontra-se simultaneamente dentro e fora do ordenamento jurídico: dentro, pois ele tem a prerrogativa legal de decidir sobre a suspensão da lei; fora, pois o que ele decide é, legalmente, sobre a suspensão da própria lei -, e na zona de indiferença entre regra e vida que ela cria, a partir da suspensão da lei, que a vida é capturada pelo ordenamento, sob a forma topológica da exceptio (inclusão exclusiva ou exclusão inclusiva). E se a exceção é, na verdade, a estrutura da soberania, então ela não é um conceito nem exclusivamente político, nem uma categoria exclusivamente jurídica, nem uma potência externa ao direito (a decisão, como diria Carl Schmitt), nem a norma suprema do ordenamento jurídico (como diria Hans Kelsen), mas "[...] a estrutura originária na qual o direito se refere à vida e a inclui em si através da própria suspensão" (AGAMBEN, 2010a, p. 35). E essa relação, propõe Agamben (2010a, p. 35), é uma relação de bando:

Retomando uma sugestão de Jean-Luc Nancy, chamemos de bando (do antigo termo germânico que designa tanto a exclusão da comunidade quanto o comando e a insígnia do soberano) a esta potência (no sentido próprio da dýnamis aristotélica, que é sempre também dýnamis mè energeîn, potência de não passar ao ato) da lei, de manter-se na própria privação, de aplicar-se desaplicando-se. A relação de exceção é uma relação de bando. Aquele que foi banido não é, na verdade, simplesmente posto fora da lei e indiferente a esta, mas é abandonado por ela, ou seja, exposto e colocado em risco no limiar em que vida e direito, externo e interno, se confundem. Dele não é literalmente possível dizer que

\footnotetext{
34 Nesse sentido, vale menção esta essencial passagem na qual Agamben (2010a, p. 25) define a relação de exceção: "A exceção que define a estrutura da soberania é, porém, ainda mais complexa. Aquilo que está fora vem aqui incluído não simplesmente através de uma interdição ou um internamento, mas suspendendo a validade do ordenamento, deixando, portanto, que ele se retire da exceção, a abandone. Não é a exceção que se subtrai à regra, mas a regra que, suspendendo-se, dá lugar à exceção e somente deste modo se constitui como regra, mantendo-se em relação com aquela. O particular 'vigor' da lei consiste nessa capacidade de manter-se em relação com uma exterioridade. Chamemos relação de exceção a esta forma extrema da relação que inclui alguma coisa unicamente através de sua exclusão".

35 "Soberano é quem decide sobre o estado de exceção" (SCHMITT, 2006, p. 7).
} 
esteja fora ou dentro do ordenamento (por isto, em sua origem, in bando, a bandono significam em italiano tanto "à mercê de" quanto "a seu talante, livremente", como na expressão correre a bandono, e bandito quer dizer tanto "excluído, posto de lado" quanto "aberto a todos, livre", como em mensa bandita e a redina bandita). É neste sentido que o paradoxo da soberania pode assumir a forma: "não existe um fora da lei". A relação originária da lei com a vida não é a aplicação, mas o Abandono. A potência insuperável do nómos, a sua originária "força de lei" é que ele mantém a vida em seu bando abandonando-a.

A vida nua se encontra desde sempre, portanto, em uma relação de exceção, que Agamben chama de relação de bando. O significado desta palavra, conforme explicita Giacoia Junior (2008, p. 38) remete a bandido, mas também a banido, excluído, da mesma maneira que os termos Bande e Bann, e designam tanto a exclusão da comunidade quanto o comando e a insígnia do poder soberano. Este termo remete à potência da lei de manter-se na própria privação, ele é, de acordo com Agamben (2010a, p. 109), “[...] essencialmente o poder de remeter algo a si mesmo, ou seja, o poder de manter-se em relação com um irrelato pressuposto". O bando tem, como tal, a capacidade, em relação à vida, de "capturá-la fora" (ex-capere) do ordenamento e, assim, “[...] na medida em que a aplicação (incidência) da decisão soberana consiste precisamente na exclusão e suspensão da lei e da paz, fazendo coincidir, num mesmo ato, suspensão (exclusão) e aplicação (inclusão)" (GIACOIA JUNIOR, 2008, p. 38), seguindo a lógica da estrutura da soberania, ele termina por ser a força simultaneamente atrativa e repulsiva que liga os dois polos do poder, ou seja, a vida nua e o poder soberano, sendo precisamente este o motivo pelo qual ele pode significar tanto a própria insígnia da soberania quanto a exclusão da comunidade (AGAMBEN, 2010a, p. 110).

Desta maneira, a vida nua segue simultaneamente excluída e capturada, sendo incluída no ordenamento jurídico por meio de sua própria suspensão, o que acarreta como principal consequência o fato de que aquele que foi banido não é simplesmente posto fora da lei ou sentido por ela de maneira indiferente, mas é, em verdade, por ela abandonado, ou seja, exposto e colocado no limiar em que vida e direito se tornam indiscerníveis (AGAMBEN, 2010a, p. 35). E se o fundamento da violência soberana reside nesta exceptio da vida nua no Estado, isso significa, também, que o seu referente imediato é desde sempre aquela vida matável e insacrificável que tem no homo sacer o seu maior paradigma, motivo pelo qual se pode de fato afirmar, na linha dos argumentos de Giorgio Agamben (2010a, p. 106), que autenticamente política é somente a vida nua.

Como consequência, tem-se que, no íntimo, aquilo que deve ser apreendido no interior das relações políticas e dos espaços públicos em que vivemos é, portanto, a estrutura do bando, o verdadeiro nómos soberano, o qual condiciona todas as demais 
normas, a espacialização originária que torna possível toda a localização e toda a territorialização. Por fim, de acordo com Agamben (2010a, p. 110), se na modernidade a vida veio a se tornar cada vez mais claramente o objeto da política, tornando-se biopolítica, nos termos de Foucault, e se em nosso tempo em um sentido muito particular, porém, no entanto, extremamente real, todos os cidadãos vêm a se tornar virtualmente sagrados, deve-se isto ao fato de que a relação de bando é que constituía desde a origem a verdadeira estrutura do poder soberano. ${ }^{36}$

E talvez seja, afinal, precisamente este o arcana imperii que, ainda não suficientemente discutido, termine por destinar a vida nua do cidadão, enquanto novo corpo biopolítico da humanidade, à toda insensatez de um sistema intrinsecamente violento, além do qual, infelizmente, ainda não se vislumbra nenhuma saída.

\section{Referências}

AGAMBEN, Giorgio. A comunidade que vem. Tradução e notas de Cláudio Oliveira. Belo Horizonte: Autêntica, 2013.

. A linguagem e a morte: um seminário sobre o lugar da negatividade. Tradução de Henrique Burigo. Belo Horizonte: Editora UFMG, 2006.

. Como a obsessão por segurança muda a democracia. Le Monde Diplomatique Brasil, São Paulo, ano 7, v. 78, jan. 2014. Disponível em: https://diplomatique.org.br/como-a-obsessao-porseguranca-muda-a-democracia. Acesso em: 29 jan. 2019.

. Homo Sacer: o poder soberano e a vida nua I. Tradução de Henrique Burigo. 2. ed. Belo Horizonte: Editora UFMG, 2010a.

. Meios sem fim: notas sobre a política. Tradução de Davi Pessoa Carneiro. Belo Horizonte: Autêntica Editora, 2015a.

. O reino e a glória: uma genealogia teológica da economia e do governo: homo sacer, II, 2. Tradução de Selvino J. Assmann. São Paulo: Boitempo, 2011. (Estado de sítio).

. Profanações. Tradução e apresentação de Selvino José Assmann. São Paulo: Boitempo, 2007.

. Signatura rerum: sobre el método. Traducción de Flavia Costa y Mercedes Revituso. Barcelona: Editorial Anagrama, 2010b.

36 Dito de outro modo, com Daniel Arruda Nascimento (2012, p. 128), “[...] o que a teoria clássica da soberania parece desconhecer ou encobrir é o reconhecimento de que o fato da dominação pode ser a fonte originária e permanente do direito". 
AGAMBEN, Giorgio. Stasis: la guerra civile come paradigma politico. Homo sacer, II, 2. 1. ed. Turim: Bollatti Boringhieri, 2015b.

ASSMANN, Selvino José; BAZZANELlA, Sandro Luiz. A máquina/dispositivo política: a biopolítica, o estado de exceção, a vida nua. In: LONGHI, Armindo José (org.). Filosofia, política e transformação. São Paulo, SP: LiberArs, 2012.

BENJAMIN, Walter. O anjo da história. Organização e tradução de João Barrento. 2. ed. 1. reimp. Belo Horizonte: Autêntica, 2016.

BENVENISTE, Émile. Vocabulario de las instituciones indoeuropeas. Madrid: Taurus, 1983.

CASTRO, Edgardo. Introdução a Foucault. Tradução de Beatriz de Almeida Magalhães. 1. ed. Belo Horizonte: Autêntica, 2014.

. Introdução a Giorgio Agamben: uma arqueologia da potência. Tradução de Beatriz de Almeida Magalhães. 1. ed. 1. reimp. Belo Horizonte: Autêntica, 2013.

DE LA DURANTAYE, Leland. Giorgio Agamben: a critical introduction. Stanford: Stanford University Press, 2009.

DUARTE, André de Macedo. De Michel Foucault a Giorgio Agamben: a trajetória do conceito de biopolítica. In: SOUZA, Ricardo Timm de; OLIVEIRA, Nythamar Fernandes. Fenomenologia hoje III: bioética, biotecnologia, biopolítica. Porto Alegre: Editora da PUCRS, 2008. v. 3, p. 63-87. Disponível em: http://works.bepress.com/andre_duarte/17. Acesso: 28 jan. 2019.

ESPOSITO, Roberto. Bios: biopolítica e filosofia. Tradução de Wander Melo Miranda. Belo Horizonte: Editora UFMG, 2017.

FONSECA, Márcio Alves da. Michel Foucault e o direito. 2. ed. São Paulo: Max Limonad, 2012.

FOUCAULT, Michel. A ordem do discurso: aula inaugural no Collège de France, pronunciada em 2 de dezembro de 1970. Tradução de Laura Fraga de Almeida Sampaio. 24. ed. São Paulo: Loyola, 2014a.

. Em defesa da sociedade: curso no Collège de France (1975-1976). Tradução de Maria Ermantina de Almeida Prado Galvão. 2. ed. São Paulo: WMF Martins Fontes, 2010.

. História da sexualidade 1: a vontade de saber. Tradução de Maria Thereza da Costa Albuquerque. 4. ed. Rio de Janeiro/São Paulo: Paz e Terra, 2017.

. Segurança, território, população: curso dado no Collège de France (1977-1978). Tradução de Eduardo Brandão. Revisão da tradução de Claudia Berliner. São Paulo: Martins Fontes, 2008.

. Vigiar e punir: nascimento da prisão. Tradução de Raquel Ramalhete. 42. ed. Petrópolis, Rio de Janeiro: Vozes, 2014b. 
GIACOIA JUNIOR, Oswaldo. Notas sobre direito, violência e sacrifício. DoisPontos, Curitiba, São Carlos, v. 5, n. 2, p. 33-47, out. 2008. Disponível em: https://revistas.ufpr.br/doispontos/article/ view/14659/9838. Acesso em: 12 abr. 2019.

JHERING, Rudolf Von. O espírito do direito romano: nas diversas fases do seu desenvolvimento. Tradução de Rafael Benaion. Prefácio de Clóvis Beviláqua. Rio de Janeiro: Alba, 1943. v. 1.

MAUSS, Marcel; HUBERT, Henri. Sobre o sacrificio. Tradução de Paulo Neves. São Paulo: Cosac Naify, 2005.

NASCIMENTO, Daniel Arruda. Do fim da experiência ao fim do jurídico: percurso de Giorgio Agamben. São Paulo: LiberArs, 2012.

SCHMITT, Carl. Dictatorship: from the origin of the modern concept of sovereignty to the proletarian class struggle. Translated by Michael Hoelzl and Graham Ward. Cambridge: Polity Press, 2014.

. Teologia política. Tradução de Elisete Antoniuk. Coordenação e supervisão Luiz Moreira. Belo Horizonte: Del Rey, 2006. 